\title{
Temporal distribution of genetically homogenous 'free-living' Hematodinium sp. in a Delmarva coastal ecosystem
}

\author{
Joseph S Pitula ${ }^{1 *}$, Whitney D Dyson ${ }^{1}$, Habibul B Bakht ${ }^{1}$, Ihuoma Njoku² and Feng Chen ${ }^{2}$
}

\begin{abstract}
Background: Significant damage to crustacean fisheries worldwide has been associated with Hematodinium sp. It has been postulated that Hematodinium sp. requires passage through the water column and/or intermediate hosts to complete its life cycle. Thus, an understanding of the prevalence and seasonality of Hematodinium sp. within environmentally-derived samples should yield insight into potential modes of disease transmission, and how these relate to infection cycles in hosts.

Results: We conducted a two year survey, from 2010-2011, in which 48 of 546 (8.8\%) of environmental samples from the Maryland and Virginia coastal bays were positive for Hematodinium sp. between April and November, as based upon endpoint PCR analysis specific to blue crab isolates. Detection in both water and sediment was roughly equivalent, and there were no obvious seasonal patterns. However, there was a high detection in April water samples, which was unanticipated owing to the fact that crabs infected with Hematodinium sp. have not been observed in this early month of the seasonal disease cycle. Focusing on three sites of high prevalence (Sinnickson, VA; Tom's Cove, VA; and Newport Bay, MD) Hematodinium sp. population diversity was analyzed using standard cloning methods. Of 131 clones, 109 (83.2\%) were identical, 19 displayed a single nucleotide substitution, and 4 contain two nucleotide substitutions.

Conclusions: Our data suggests a continuous presence of Hematodinium sp. in both water and sediment of a combined Maryland and Virginia coastal bay ecosystem. The detection of Hematodinium sp. in the water column in April is an earlier manifestation of the parasite than predicted, pointing to an as yet unknown stage in its development prior to infection. That the population is relatively homogenous ranging from April to November, at three distinct sites, supports a hypothesis that one species of Hematodinium is responsible for infections within the ecosystem.
\end{abstract}

Keywords: Hematodinium, Life cycle, Environment, Population

\section{Background}

The blue crab (Callinectes sapidus) fishery is of critical importance to the economics of the Chesapeake Bay region. In the United States over a third of all blue crabs come from this fishery [1]. In 2010 approximately 92 million pounds were harvested from the Chesapeake Bay and its tributaries, representing the largest amount since 1994 [2]. Blue crab populations have historically experienced regular population fluctuations, with a recent

\footnotetext{
* Correspondence: jspitula@umes.edu

'Department of Natural Sciences, University of Maryland Eastern Shore,

Princess Anne, MD 21853, USA

Full list of author information is available at the end of the article
}

surge attributed to improved stock management practices. In the context of efforts to sustain a vigorous fishery, it is critical to monitor disease-causing agents such as the dinoflagellate parasite Hematodinium sp.

Worldwide, significant damage to crustacean fisheries has been associated with Hematodinium sp. as observed in Alaska Tanner and snow crabs (Chionoecetes spp.), and the Norway lobster (Nephrops norvegicus) from European waters [3-5]. Recognition of the broad ecological range of this parasite has led to increasing reports of infection in various fisheries [6-8]. In many affected crustacean species disease manifests as shell discoloration and 'chalky' hemolymph, discouraging human consumption [3]. In

\section{Biomed Central}


blue crabs the disease prevalence has been reported to be as high as $90 \%$ in Maryland and Delaware coastal bays [9], and thus the biological impact on crab survival and reproduction is likely to be significant.

An important question to be resolved is how crustaceans acquire the disease. A preliminary transmission study supported a hypothesis that wild blue crabs acquire the parasite through cannibalism and/or predation on other infected prey. In this study 11 naïve crabs were fed five grams of Hematodinium-infected crabmeat, and six became infected through this route [10]. However, this has been contradicted by a more recent study using a similar approach. Extremely low transmission rates were observed, and it was concluded that crabs that developed disease were most likely harboring low-level infections prior to the experiment [11]. Concurrent with these studies is a growing body of evidence that Hematodinium sp. may be present within marine ecosystems as short-lived dinospores [12,13], and also associated with potential zooplankton vectors, such as amphipods and crab larvae [14-16]. It is thus likely that, in nature, Hematadinium sp. requires passage through the water column and/or intermediate hosts to complete its life cycle $[12,17]$.

Among diverse crustaceans, disease prevalence occurs on a seasonal basis. For the blue crab, peak infections occur between late summer to autumn $[9,18]$. By contrast, six crustacean species in the Clyde Sea of Scotland displayed two peaks of infection during the year. The highest peak typically occurred between February to April, with a smaller peak for several species in November [19-21]. An understanding of the prevalence and seasonality of Hematodinium sp. within environmentally-derived samples should yield insight into potential modes of disease transmission to various hosts.

We report on the detection of blue crab-specific Hematodinium sp. in the water column and sediment from 18 sampling sites within Maryland and Virginia coastal waters. The temporal distribution and genetic diversity of Hematodinium sp. in these samples was analyzed by cloning and sequencing methods. Our results suggest a persistent presence of Hematodinium sp. between April and November, with a relatively homogenous population structure.

\section{Results}

\section{Hematodinium in water and sediment}

Two seasonal surveys were conducted for the environmental presence of Hematodinium sp. Eighteen sites within Maryland and Virginia coastal bays were investigated, encompassing the Sinnepuxent, Newport, and Chincoteague Bays, south of the Ocean City, MD inlet (Figure 1). The time frame for sampling was initiated with emergence of blue crabs from winter hibernation in April
2010, through late summer to early autumn, and into winter hibernation beginning in November 2010. This sampling regimen was repeated in 2011 and permitted for investigation of known Hematodinium-positive sites during periods prior to, and throughout, a seasonal pattern of high prevalence in summer and low to non-existent infections during the winter. Sediment and plankton samples were collected from each site, and the DNA from the biota present was extracted for further analysis (see Materials and Methods).

Endpoint PCR-based analysis, using Hematodiniumspecific primers, detected 48 of 546 sample sites (8.8\%) as positive, based upon observation of a definitive band corresponding to the predicted amplicon length of 285 bp (data not shown). The distribution was relatively even throughout all months, and also between plankton and sediment samples, although positive detections for 2010 were higher than in 2011 (Table 1). In addition, Hematodinium sp. was never detected in water samples in May or November. Varying environmental parameters, such as dissolved oxygen and water temperature differences, did not correlate to any patterns in detection (data not shown). Three widely dispersed locations (sites 12,16 , and 17) were never positive in our assays.

\section{Hematodinium and other dinoflagellates in the water column}

Collectively, our data suggested that putative freeliving Hematodinium sp. maintain a continuous environmental presence in water and/or sediment in the Delmarva coastal ecosystem. During 2010 Sinnickson, VA (site 10) was positive in our PCR screen for all months in either water or sediment, and in addition it was one of four sites in which water samples were positive in April (Table 1). The April water data was of particular interest as during this month crab infections have never been reported, and thus release of Hematodinium sp. cells from diseased crabs was unlikely. As Sinnickson represented a potential hotspot for environmental transmission, we sought to further explore the dinoflagellate population structure from water samples at this site.

To detect Hematodinium sp., along with other dinoflagellates, we generated an $18 \mathrm{~S}$ rRNA clone library that targeted a conserved region of the gene. We reasoned that enumeration of Hematodinium sp. within the library would yield a rough estimate of its abundance relative to other free-living dinoflagellate species, in addition to confirming our temporal observations. The seasons in which various dinoflagellate species are known to bloom has been established in the related ecosystem of Chesapeake Bay [22], and thus their presence in specific months provided an internal control for dinoflagellate population structure analysis. 


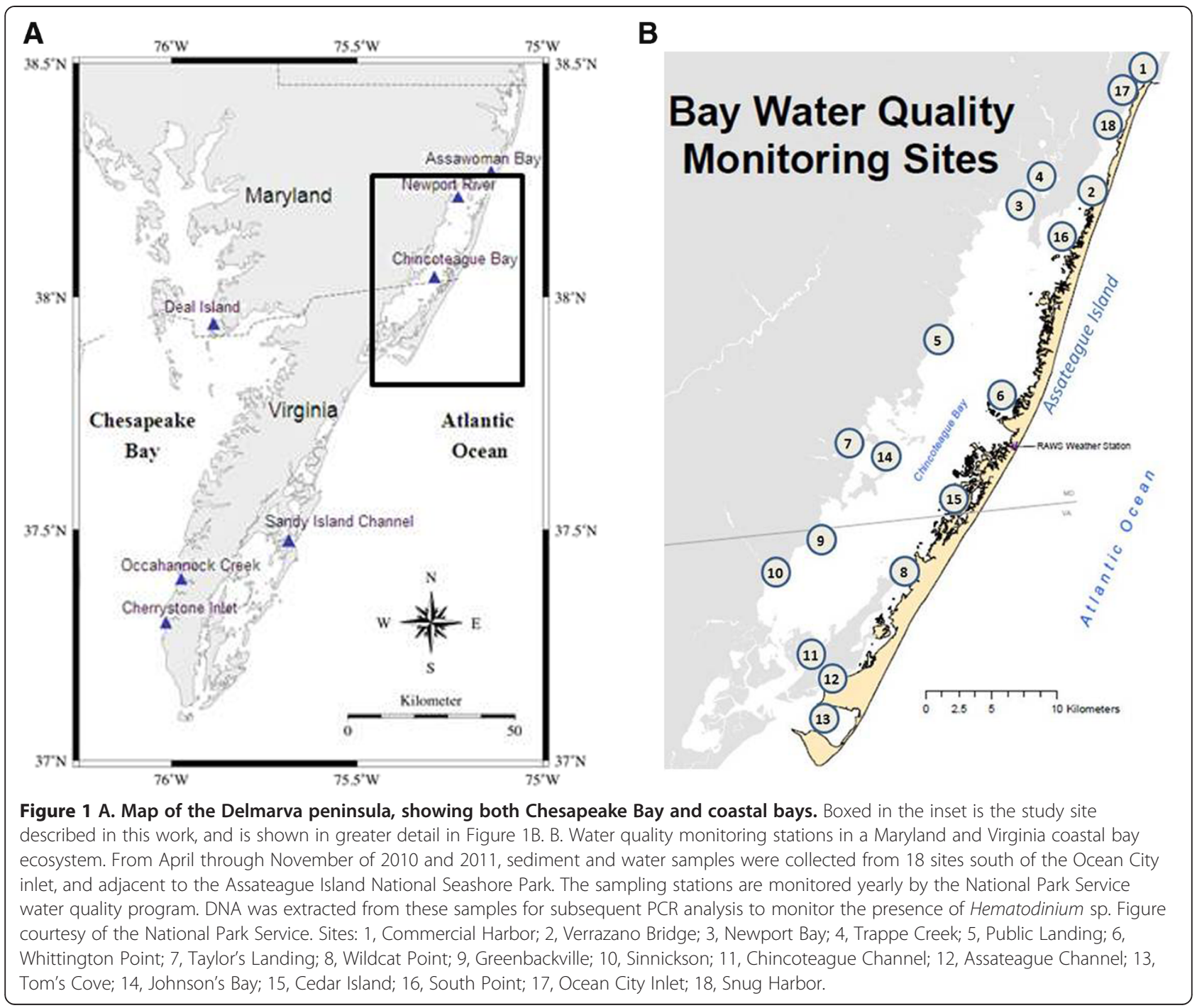

Dinoflagellate 18 S rRNA clone library results for Sinnickson in 2010 are presented in Table 2 and Figure 2, subdivided into categories of early spring (April), late spring (June), summer (July/August), and autumn (October). In total, Hematodinium sp. was detected in $40 / 70(57 \%)$ of water samples. This percentage was unexpectedly high, and may represent some unknown sampling bias. The plankton filter used has a pore size of $20 \mu \mathrm{m}$ which in theory should allow released amoeboid trophonts, in addition to individual micro- and macrodinospores, to pass though the net [17], but would still retain cells either in the process of division or in clumps. Alternatively, cells may associate with small plankton or particulates. Surprisingly, analysis of individual months revealed that April has the highest relative prevalence (15/16 or $94 \%$ ) for Hematodinium sp. (see Figure 2). The temporal distribution of other dinoflagellates was consistent with the succession pattern from Chesapeake Bay [22]. Heterocapsa rotundata, commonly present in
Chesapeake Bay through winter and spring, represented $77 \%(10 / 13)$ of the clones from June sequences. In summer and early autumn a mix of species that included $H$. rotundata and Gymnodinium sp. was observed, although the majority of dinoflagellates remained Hematodinium sp. (23/41 or $56 \%)$.

A phylogenetic analysis of the 2010 Sinnickson samples was also performed (Figure 3). Of the 40 Hematodinium sp. clones in the library, 35 were identical and are labeled in the phylogenetic tree as "The consensus sequence." Five other Hematodinium sp. clones, from the months indicated, contained single nucleotide polymorphisms, with the exception of April clone b which had two (data not shown). The Hematodinium sequences detected in the Sinnickson samples were more closely related to an isolate from Callinectes sapidus than to Hematodinium spp. isolated from other non-portunid host crustacean species such as Cancer pagurus and Carcinus maenas. Other representative dinoflagellate clones from the 2010 Sinnickson 
Table 1 Hematodinium sp. presence in a coastal bay ecosystem

\begin{tabular}{|c|c|c|c|}
\hline & & Water collection dates & Sediment collection dates \\
\hline Site 1 & Commercial Harbor & 7_10 & 8_11 \\
\hline Site 2 & Verrazano Bridge & $9 \_10$ & 4_10; 5_10; 7_10; 8_11 \\
\hline Site 3 & Newport Bay & 6_10;9_10 & 6_10;8_11 \\
\hline Site 4 & Trappe Creek & $4 / 10 ; 7 / 10$ & 8_11 \\
\hline Site 5 & Public Landing & 6_10;9_10 & 5_10;8_11 \\
\hline Site 6 & Whittington Point & & 8_10;8_11 \\
\hline Site 7 & Taylor's Landing & $4 / 10 ; 6 / 10 ; 7 / 10$ & \\
\hline Site 8 & Wildcat Point & & 8_10;8_11 \\
\hline Site 9 & Greenbackville & $6 \_10$ & 8_11 \\
\hline Site 10 & Sinnickson & 4_10;6_10; 7_10; 8_10; 10_10 & 5_10; 7_10; 8_10; 10_10; $11 \_10$ \\
\hline Site 11 & Chincoteague Channel & 7_10 & \\
\hline Site 13 & Tom's Cove & $6 \_11$ & 8_10; 10_10; 8_11 \\
\hline Site 14 & Johnson's Bay & $4 \_10 ; 6 \_10$ & \\
\hline Site 15 & Cedar Island & 7_10 & \\
\hline Site 18 & Snug Harbor & 10_10 & 4_10;6_10 \\
\hline
\end{tabular}

Shown are the sites and dates in which Hematodinium sp. detection occurred, based upon gene-specific PCR analysis. The sites correspond to those labeled in Figure 1B. Dates are indicated by the month, followed by the year. Typically sampling was conducted in the second week of each month, unless weather conditions precluded collection to the third week.

library are also included, and they are related to a diverse group of dinoflagellates (Figure 3).

\section{Sequence analysis of Hematodinium clones}

It has been suggested that the species of Hematodinium infecting crabs in the waters of the Delmarva Peninsula is a host generalist, based on the high sequence identity of the ITS-1 region from various infected crustaceans [16]. This observation is consistent with similar data derived from analysis of both clade A and clade B Hematodinium disease systems [23]. We were thus interested to analyze the population structure in our study, particularly as the temporal distribution patterns suggests a continuous environmental presence at hotspot sites such as at Sinnickson, VA in 2010. In addition

Table 2 Dinoflagellate species present in water samples from Sinnickson, VA in $\mathbf{2 0 1 0}$

\begin{tabular}{lll}
\hline Hematodinium & $\begin{array}{l}\text { Other } \\
\text { species }\end{array}$ & \\
\hline April & $15 / 16$ & 1 unidentified nanoflagellate \\
June & $2 / 13$ & $\begin{array}{l}10 \text { Heterocapsa rotundata, } \\
1 \text { Peridinium sp. }\end{array}$ \\
July/August & $13 / 25$ & 3 Gymnodinium sanguineum, \\
& & 1 Gymnodinium sp., $3 \mathrm{H}$. rotundata \\
& & and 5 unidentified eukaryotic clones. \\
October & 2 Pentapharsodinium tyrrhenicum, \\
& $10 / 16$ & G. simplex, 1 Gymnodinium sp., \\
& & 1 H. rotundata and 1 Dinophyceae sp.
\end{tabular}

Shown are sequencing results from analysis of libraries generated using dinoflagellate-specific $18 \mathrm{~S}$ rRNA. to Sinnickson, we concurrently analyzed Tom's Cove, VA and Newport Bay, MD (sites 10, 13, and 3 respectively). These locations produced $37.5 \%$ (18/48) of the total positive identifications, and also represent distributions that are in the northwest, southwest, and southeast ends of Chincoteague Bay (see Figure 1B).

Clone libraries were generated from PCR products amplified by the Hematodinium-specific ITS1/5.8 S rRNA primers used in our initial detection assays. In Table 3 is a comparison of the relative identity of our clones derived from three hotspots of environmental presence. The populations were homogeneous, with approximately $83.2 \%$ of all clones identical (109/131). Of

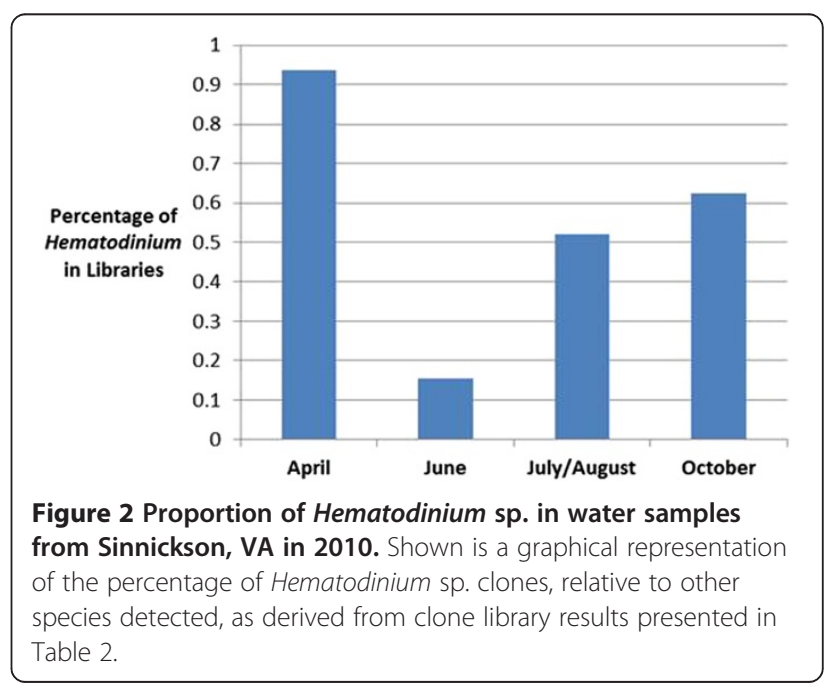




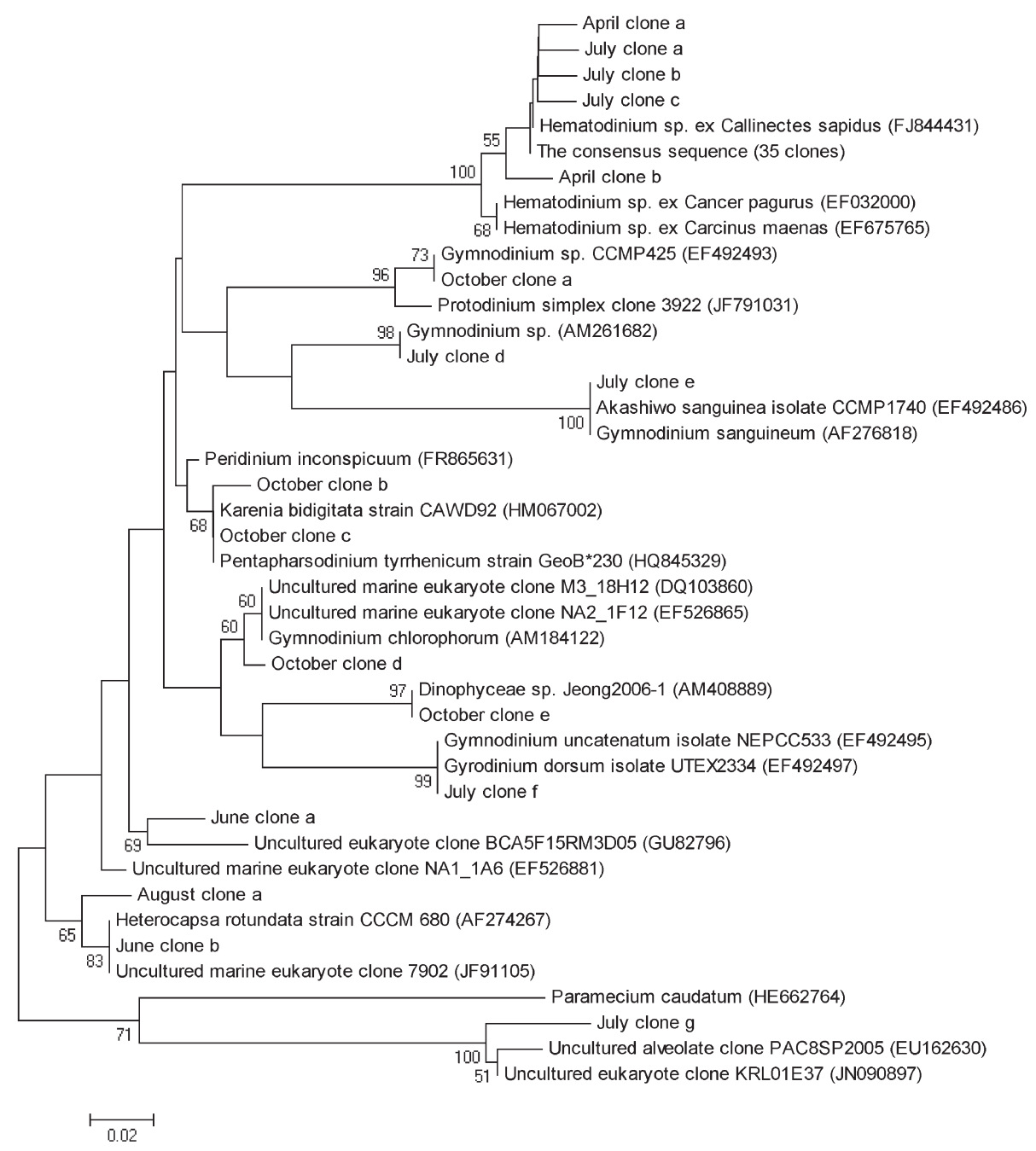

Figure 3 Phylogenetic analysis based on the partial 18 S rRNA gene sequences retrieved from clone libraries. The un-rooted Neighborjoining tree was constructed based on the aligned DNA sequences with bootstrap value of 100, with bootstrap values less than 50 not shown.

the remaining 22, 18 contained single nucleotide polymorphisms (SNPs). Surprisingly, these SNPS did not predominantly cluster in the ITS-1 region of the amplicon, as 10 of the 18 clones contained substitutions in the $5.8 \mathrm{~S}$ rRNA gene.

An alignment of the dominant clones in our libraries is shown in Figure 4 contrasted to sequence from a Hematodinium sp. isolated from an infected blue crab. A SNP between these is located at position 40 of the 5.8 S rRNA, with G substituting for A. However, it should be noted that a single clone in our library matched identically with these alternative sequences. Also shown in the alignment are the four clones containing two substitutions. Despite these minor differences, all samples were $>98.5 \%$ identical or higher in sequence, suggesting a genetically homogenous population that is likely derived from a single species.

\section{Discussion}

The in vitro life cycle of Hematodinium species has been characterized by culturing methods $[17,24]$. These, along with other studies $[3,13]$, have supported a hypothesis for the mode of disease transmission in nature to entail infective dinospores, as a small portion of cultured dinospores develop into filamentous trophonts [17]. As the filamentous trophont is routinely observed in infected crustaceans from field studies $[4,8,11]$, it is possible that released dinospores from these hosts may develop into trophonts in the water column and/or an intermediate vector. Alternatively, the dinospore may itself be the infectious stage, or may require a preparatory cyst phase. In order to explore these life cycle questions in a coastal bay ecosystem, it was important to first search for the chronological manifestations of Hematodinium sp. within the study site. 
Table 3 Relative identity of Hematodinium clones derived from three hotspots of environmental presence

\begin{tabular}{lll}
\hline & Identical sequence & Percentage \\
\hline Sinnickson & $13 / 16$ & $81 \%$ \\
p/w April 2010 & $3 / 3$ & $100 \%$ \\
Sed August 2010 & $25 / 27$ & $93 \%$ \\
Sed November 2010 & & \\
Tom's Cove & $12 / 14$ & $86 \%$ \\
p/w June 2010 & $16 / 20$ & $80 \%$ \\
Sed August 2010 & $25 / 36$ & $69 \%$ \\
Sed November 2010 & & \\
Newport Bay & $5 / 5$ & $83 \%$ \\
p/w June 2011 & $10 / 12$ & $83 \%$ \\
Sed June 2010 & $109 / 131$ & \\
Total & &
\end{tabular}

Clone libraries were generated from Hematodinium-specific ITS1/5.8 S rRNA primers used in our initial detection assays, with locations and dates of analysis. Identical sequences were present in $83 \%$ of the clones in the libraries. $\mathrm{p} / \mathrm{w}$ : plankton-water samples; Sed: sediment samples.

Based on a preliminary PCR-based screen, Hematodinium sp. was equally distributed in both water and sediment samples collected in 2010 and 2011 (Table 1). In most cases we detected parasite DNA in only water or sediment, but not both, for positive sites. The only exceptions were at Newport Bay, MD in June of 2010, and Sinnickson, VA in July, August, and October of 2010.

That Hematodinium sp. was detectable in sediment during all months was expected, as we anticipated that both free-living forms, in addition to parasites from degraded crab tissue, would be present. By contrast it was predicted that the preponderance of detections in water samples would be between June-November, as these months have traditionally been those in which blue crabs have their highest prevalence and intensity of infection $[16,18]$, and are thus most likely to be releasing dinospores. Surprisingly, $17.4 \%(4 / 23)$ of our water column detections occurred in April 2010 when little or no dinospores were anticipated to be present in the water column. To our knowledge this is the earliest environmental identification of Hematodinium sp. in this ecosystem. Previous work in a Virginia coastal ecosystem detected Hematodinium sp. in the water column, but in the month of November 2007 [13]. It should be noted that a study conducted in a Georgia estuary system in 1999 and 2000 also tested for Hematodinium sp. in the environment prior to disease in blue crabs. It was not detectable in surface waters in March or April, but was detectable in May when blue crabs began to manifest disease [12].

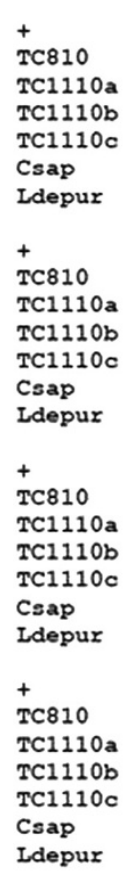

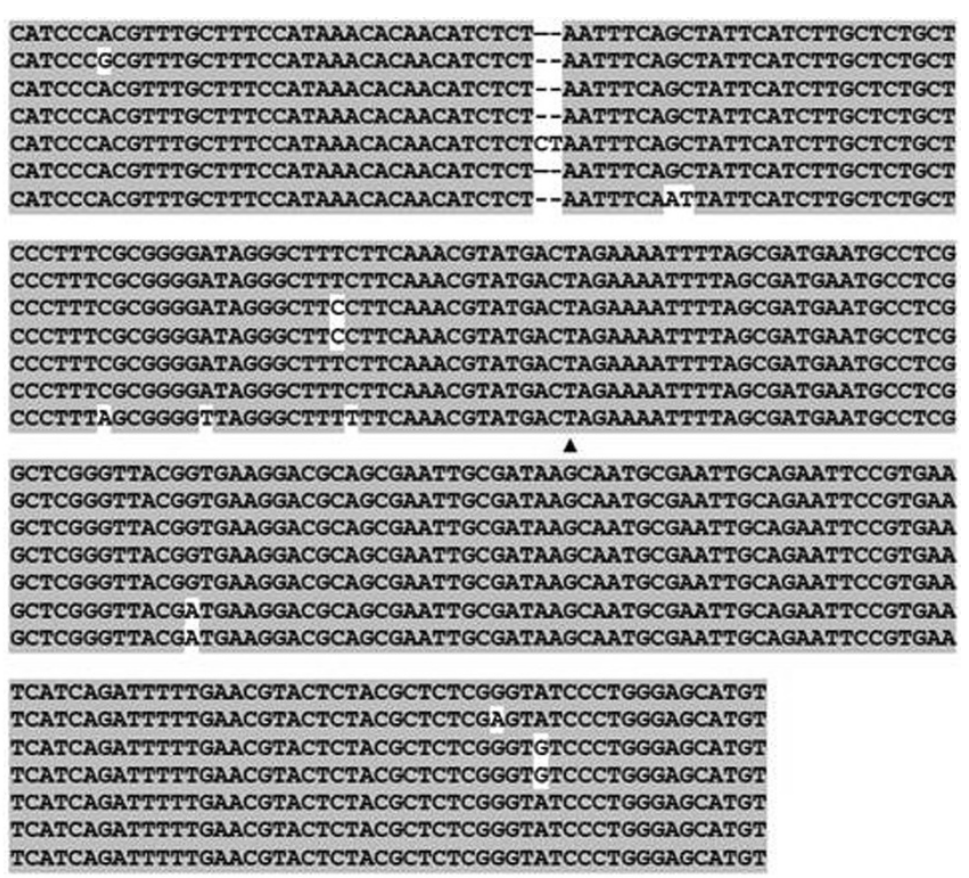

Figure 4 Sequence alignment of Hematodinium sp. clones. The consensus sequence from 131 environmental clones, derived from 109 identical sequences, is designated by " + ", and is aligned with the four most divergent clones in the library; one clone from Tom's Cove (TC) in August, and three from November. Also shown is alignment with GenBank sequences from C. sapidus isolates (Csap: Accession DQ925229 joined with JN641990) and the portunid crab Liocarcinus depurator (Ldepur: Accession EF153729 joined with JN641974). The triangle ( $\mathbf{A}$ ) indicates the boundary between ITS1 and the $5.8 \mathrm{~S}$ rRNA gene. 
To further investigate the temporal manifestation of Hematodinium sp. in water we analyzed samples acquired from Sinnickson, VA (site 10), which in 2010 was a "hotspot" of environmental detection. Using primers targeting the $18 \mathrm{~S}$ rRNA of dinoflagellates, the presence of Hematodinium sp. was confirmed within the ecological context of other resident species (Table 2). Although not strictly quantitative, the distribution of Hematodinium sp. clones in these months was intriguing, particularly its relative abundance in April. This month yielded 15/16 (94\%) of sequences that matched Hematodinium sp., and coincides with the peak abundance of $20-40 \mathrm{~mm}$ carapace width juveniles (MDDNR personal communication,). It is also known that, in this ecosystem, juveniles have the highest disease prevalence [18]. Thus the presence of Hematodinium sp. in the water column at this stage may point to an important means of disease acquisition, as it is known with Chionoecetes opilio that actively molting crabs acquire infection [25]. It should be noted that the sampling method used in this study was capable of harvesting free-living Hematodinium sp., potentially in association with zooplankton. It has been suggested that macrozooplankton, such as amphipods or crustacean larvae, may harbor parasites [16,21]. In April, amphipods as vectors are a reasonable supposition. However, blue crab larval vectors during this month are unlikely, as release of larvae from females does not typically occur until May in this ecosystem.

The vast majority of Hematodinium sp. infections in the Chesapeake Bay region occur in the predominant crustacean species, $C$. sapidus, which has been classified as a clade A host species [26]. A recent study from Delmarva Peninsula waters has suggested that a single species is responsible for all infections [16]. We thus examined the population structure of Hematodinium sp. from sites that showed a high environmental presence, to determine if these reservoirs maintained one genetically homogenous species or other potential sub-species. All 131 clones from our libraries were $>98.5 \%$ identical, with only four clones containing two nucleotide substitutions (Figure 4). Based on this particular ribosomal marker, our results suggest that the diversity of Hematodinium sp. in the Maryland Coastal Bays is low.

The consensus ITS-1 sequence in our clones is identical to ITS-1 sequences recently reported for five xalternate host species from Delmarva waters (Accession \#: JN368194, JN368172, JN368154, JN368162, and JN368158) which are the: skeleton shrimp (Caprella geometrica), atlantic mud crab (Panopeus herbstii), longnosed spider rab (Libnia dubia), depressed mud crab Eurypanopeus depressus, and flat-clawed hermit crab (Pagurus pollicaris), respectively. In addition it is identical with the C. sapidus ITS-1 from an isolate in 2006
(Accession: DQ925229). Our data thus supports the previously suggested hypothesis that a single species of Hematodinium is responsible for infections in the Delmarva ecosystem [16]. ITS sequences in ribosomal genes are predicted to show the greatest variation as they are removed during ribosomal processing. Since the ITS1 consensus sequence we observed is identical to those in alternative hosts, and has not diverged significantly since 2006, two additional implications can be drawn. A) The Hematodinium sp. that infects blue crabs is not likely to have recently received new pathogen species into this ecosystem, and B) the time that it spends associated with alternative hosts is likely brief, since more variations would be predicted if its infectivity was limited to individual host species.

\section{Conclusions}

The near continuous detection of Hematodinium sp. at Sinnickson, VA, and indeed within this coastal ecosystem as a whole, suggests a dynamic interplay between the host and the environment. It has been posited that Hematodinium sp. parasitizes primarily blue crabs, cycling through various reservoir hosts either through incidental infections or by ingestion [16]. Our data indicates that a source for these potential modes of environmental transmission and/or life cycle stages will be continuous. It should be emphasized that the work presented here is not strictly quantitative, and thus the utilization of real time PCR methodologies [13] should yield more detailed insights into the life history of Hematodinium sp. in an ecological setting.

\section{Methods}

\section{Collection of samples}

From April to November of 2010 and 2011, monthly sediment and water samples were collected from 18 sites between the northern end of the Maryland coastal bays and the southern end of the Virginia coastal bays (Figure 1). The only exception was September of 2010, where only sites 2,3 , and 5 were sampled. Typically sampling was accomplished in the second week of each month, over a two-day time span, unless weather conditions delayed collection to the third week.

For sediment collection, a Ponar grab was used to collect $\sim 40 \mathrm{~g}$ of sediment, with two replicates per site. To collect phytoplankton samples, a plankton net with a $30 \mathrm{~cm}$ diameter was trawled through sub-surface water for 3 minutes at boat speeds ranging from 3-4 mph. The total water volume sampled was thus estimated to be approximately $25 \mathrm{~m}^{3}$ for each collection. The retention cup was fitted with a $20 \mu \mathrm{m}$ filter to capture phytoplankton and microzooplankton. A final volume of between 30 to $50 \mathrm{ml}$ of concentrated plankton was obtained in each trawl. Samples were frozen overnight at 
$20^{\circ} \mathrm{C}$, and thawed at room temperature without shaking (to permit for settling of larger particulate matter prior to DNA isolation).

\section{DNA isolation from water and sediment samples} Isolation of DNA from sediment and water samples was accomplished by using the UltraClean Soil DNA Isolation Kit (MoBio Laboratories) and the Illustra Tissue and Cells Genomic Prep Kit (GE Healthcare), respectively, according to the manufacturers' protocols. One gram of sediment was used per isolation, and DNA was re-suspended in a final volume of $100 \mu \mathrm{l}$ of water. For DNA isolation from water samples, $200 \mu \mathrm{l}$ was used per preparation. After DNA isolation, the samples were resuspended in water to a final volume of $100 \mu \mathrm{l}$.

\section{PCR and cloning methods}

Environmental PCR detection assays used the following primers: forward Hematodinium primer: (5'-CGCCTAC CACTGAACTCCTC-3'); reverse Hematodinium primer: (5'-TGAACAGACGCTGAGACCAG-3'). Primer design was based upon Hematodinium sp. sequence derived from a blue crab infection (Eric Schott, personal communication, Accession \# JQ815886). The forward primer anneals to a region within the 3' end of ITS-1, and was predicted to hybridize only to clade A Hematodinium species [26], as the ITS- 1 of clade B sequences available at the time we began our study showed significant divergence at this site. The reverse primer hybridizes to the junction between $5.8 \mathrm{~S}$ rRNA and ITS-2. One $\mu \mathrm{l}$ was used in each reaction, and PCR parameters were set at $58^{\circ} \mathrm{C}$ and $45 \mathrm{~s}$ for annealing, extension at $72 \mathrm{C}$ for 30 s, with amplification for 35 cycles. Electrophoresis of PCR products in 1\% agarose gels was followed by visualization with UV light after staining with ethidium bromide. For sediment samples, a positive score for detection was given for amplification in either of the two replicates.

For cloning purposes amplicons were purified from gels using the Gene Clean Kit (MP Biomedicals). Isolated products were cloned using the TOPO TA system (Invitrogen), and were sequenced at the University of Maryland Center for Marine and Environmental Sciences at the Institute of Marine and Environmental Technology (UMCES@IMET).

For PCR reactions designed to detect dinoflagellate species, the following primers from Oldach et al., 2000 [27] were used: universal dinoflagellate SSU forward primer (5'-CGATTGAGTGATCCGGTGAATAA-3'); universal eukaryotic SSU reverse primer (5'-TGATCCTTCTGCAG GTTCACCTAC-3'). Reaction conditions were set at $58^{\circ} \mathrm{C}$ and $45 \mathrm{~s}$ for annealing, extension at $72^{\circ} \mathrm{C}$ for $30 \mathrm{~s}$, with amplification for 35 cycles. Products were identified, excised from gels, and cloned as described above.

\section{Phylogenetic analysis}

The partial $18 \mathrm{~S}$ rRNA gene sequences obtained from the clone libraries were carefully checked for chimeric artifacts using the BLASTN program (http://www.ncbi. nlm.nih.gov/BLAST) and chimeric sequences were excluded from the phylogenetic analysis. Sequence alignment and phylogenetic reconstruction were performed using MEGA 5.05 software [28].

\section{Competing interests}

The authors declare that they have no competing interests.

\section{Acknowledgements}

The authors wish to thank Eric Sherry and Brian Sturgis of the National Park Service, at the Assateague Island National Seashore Park, for permitting us to accompany them during water quality monitoring of the study site. We also are grateful to Frank Morado for helpful discussions during preparation of the manuscript. This work was funded by the NOAA Educational Partnership Grant NA11SEC481002, and by the NSF Centers of Research Excellence in Science and Technology Grant Award 1036586.

\section{Author details}

'Department of Natural Sciences, University of Maryland Eastern Shore, Princess Anne, MD 21853, USA. ${ }^{2}$ University of Maryland Center for Environmental Sciences@the Institution of Marine and Environmental Technology, Baltimore, MD 21202, USA.

\section{Authors' contributions}

WED collected samples in 2010 and 2011, isolated DNA from sediment and water, and performed PCR identification assays. HB performed dinoflagellate population analysis. IN and JSP generated Hematodinium sp. population libraries. JSP and FC conceived the study and analyzed data. JSP drafted the manuscript. All authors read and approved the final manuscript.

Received: 6 April 2012 Accepted: 25 June 2012

Published: 24 July 2012

\section{References}

1. Chesapeake Bay Program: Blue Crabs. http://www.chesapeakebay.net/ issues/issue/blue_crabs\#inline.

2. Chesapeake Bay Blue Crab Advisory Report 2011. http://chesapeakebay. noaa.gov/images/stories/fisheries/KeyFishSpecies/cbsacreport2011.pdf]

3. Stentiford GD, Shields JD: A review of the parasitic dinoflagellates Hematodinium species and Hematodinium-like infections in marine crustaceans. Dis Aquat Organ 2005, 66:47-70.

4. Stentiford GD, Neil DMJ: Diseases of Nephrops and Metanephrops: a review. J Invertebr Pathol 2011, 106:92-109.

5. Morado JF: Protistan diseases of commercially important crabs: a review. J Invertebr Pathol 2011, 106:27-53.

6. Chualáin CN, Hayes M, Allen B, Robinson M: Hematodinium sp. in Irish Cancer pagurus fisheries: infection intensity as a potential fisheries management tool. Dis Aquat Organ 2009, 83:59-66.

7. Eigemann F, Burmeister A, Skovgaard A: Hematodinium sp. (Alveolata, Syndinea) detected in marine decapod crustaceans from waters of Denmark and Greenland. Dis Aquat Organ 2010, 92:59-68.

8. Ryazanova TV, Eliseikina MG, Kukhlevsky AD, Kharlamenko VI: Hematodinium sp. infection of red Paralithodes camtschaticus and blue Paralithodes platypus king crabs from the Sea of Okhotsk, Russia. J Invertebr Pathol 2010, 105:329-334

9. Messick GA: Hematodinium perezi infections in adult and juvenile blue crabs Callinectes sapidus from coastal bays of Maryland and Virginia, USA. Dis Aquat Organ 1994, 19:77-82.

10. Walker A, Lee RF, Frischer ME: Transmission of the parasitic dinoflagellate Hematodinium sp. infection in blue crabs Callinectes sapidus by cannibalism. Dis Aquat Organ 2009, 85:193-197.

11. Li C, Wheeler KN, Shields JD: Lack of transmission of Hematodinium sp. in the blue crab Callinectes sapidus through cannibalism. Dis Aquat Organ 2011, 96:249-258. 
12. Frischer ME, Lee RF, Sheppard MA, Mauer A, Rambow F, Neumann M, Brofft JE, Wizenmann T, Danforth JM: Evidence for a Free-Living Life Stage of the Blue Crab Parasitic Dinoflagelate, Hematodinium sp. Harmful Algae 2006, 5:548-557.

13. Li C, Shields JD, Miller TL, Small HJ, Pagenkopp KM, Reece KS: Detection and quantification of the free-living stage of the parasitic dinoflagellate Hematodinium sp. in laboratory and environmental samples. Harmful Algae 2010, 9:515-521.

14. Small HJ, Neil DM, Taylor AC, Atkinson RJ, Coombs GH: Molecular detection of Hematodinium spp. in Norway lobster Nephrops norvegicus and other crustaceans. Dis Aquat Organ 2006, 69:185-195.

15. Hamilton KM, Tew IF, Atkinson RJ, Roberts EC: Occurrence of the parasite genus Hematodinium (alveolata: Syndinea) in the water column. J Eukaryot Microbiol 2011, 58:446-451.

16. Pagenkopp Lohan KM, Reece KS, Miller TL, Wheeler KN, Small HJ, Shields J: The Role of Alternate Hosts in the Ecology and Life History of Hematodinium sp., a Parasitic Dinoflagellate of the Blue Crab (Callinectes sapidus). J Parasitol 2012, 98:73-84.

17. Li C, Miller TL, Small HJ, Shields JD: In vitro culture and developmental cycle of the parasitic dinoflagellate Hematodinium sp. from the blue crab Callinectes sapidus. Parasitol 2011, doi:10.1017/S0031182011001405.

18. Messick G, Shields JD: The epizootiology of a parasitic dinoflagellate, Hematodinium sp., in American blue crabs, Callinectes sapidus. Dis Aquat Organ 2000, 43:139-152.

19. Field RH, Hills JM, Atkinson RJA, Magill S, Shanks AM: Distribution and seasonal prevalence of Hematodinium sp. infection of the Norway lobster (Nephrops norvegicus) around the west coast of Scotland. ICES J Marine Sci 1998, 55:846-858.

20. Stentiford GD, Neil DM, Atkinson RJA: The relationship of Hematodinium infection prevalence in a Scottish Nephrops norvegicus population to season, moulting and sex. ICES J Marine Sci 2001, 58:814-823.

21. Hamilton KM, Shaw PW, Morritt D: Prevalence and seasonality of Hematodinium (Alveolata: Syndinea) in a Scottish crustacean community. ICES J Marine Sci 2009, 66:1837-1845.

22. Marshall $H G$, Burchardt $L$, Lacouture R: A review of phytoplankton composition within Chesapeake Bay and its tidal estuaries. J Plankton Res 2005, 27:1083-1102.

23. Small HJ, Shields JD, Moss JA, Reece KS: Conservation in the first internal transcribed spacer region (ITS1) in Hematodinium species infecting crustacean hosts found in the UK and Newfoundland. Dis Aquat Organ 2007, 75:251-258.

24. Appleton $\mathrm{PL}$, Vickerman $\mathrm{K}$ : In vitro cultivation and developmental cycle of a parasitic dinoflagellate (Hematodinium sp.) associated with mortality of the Norway lobster (Nephrops norvegicus) in British waters. Parasitology 1998, 116:115-130.

25. Shields JD, Taylor DM, Sutton SG, O'Keefe PO, Collins PW, Ings DW, Pardy AL: Epizootiology of bitter crab disease (Hematodinium sp.) in snow crabs, Chionoecetes opilio, from Newfoundland, Canada. Dis Aquat Organ 2005, 64:253-264.

26. Jensen PC, Califf K, Lowe V, Hauser L, Morado JF: Molecular detection of Hematodinium sp. in Northeast Pacific Chionoecetes spp. and evidence of two species in the Northern Hemisphere. Dis Aquat Organ 2010, 89:155-166.

27. Oldach DW, Delwiche CF, Jakobsen KS, Tengs T, Brown EG, Kempton JW, Schaefer EF, Bowers HA, Glasgow HB Jr, Burkholder JM, Steidinger KA, Rublee PA: Heteroduplex mobility assay-guided sequence discovery: Elucidation of the small subunit (18 S) rDNA sequences of Pfiesteria piscicida and related dinoflagellates from complex algal culture and environmental sample DNA pools. Proc Nat Acad Sci, USA 2000, 97:4303-4308.

28. Tamura K, Peterson D, Peterson N, Stecher G, Nei M, Kumar S: MEGA5: Molecular Evolutionary Genetics Analysis using Maximum Likelihood, Evolutionary Distance, and Maximum Parsimony Methods. Mol Biol Evol 2011, 28:2731-2739.

doi:10.1186/2046-9063-8-16

Cite this article as: Pitula et al:: Temporal distribution of genetically homogenous 'free-living' Hematodinium sp. in a Delmarva coastal ecosystem. Aquatic Biosystems 2012 8:16.

\section{Submit your next manuscript to BioMed Central and take full advantage of:}

- Convenient online submission

- Thorough peer review

- No space constraints or color figure charges

- Immediate publication on acceptance

- Inclusion in PubMed, CAS, Scopus and Google Scholar

- Research which is freely available for redistribution 